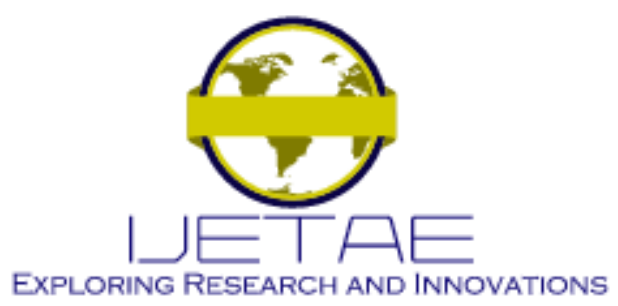

International Journal of Emerging Technology and Advanced Engineering

Website: www.ijetae.com (E-ISSN 2250-2459, Scopus Indexed, ISO 9001:2008 Certified Journal, Volume 12, Issue 01, January 2022)

\title{
Adoption of Design Thinking, Agile Software Development and Co-creation: A Qualitative Study towards Digital Banking Innovation Success
}

\author{
Elisa Indriasari ${ }^{1}$, Harjanto Prabowo ${ }^{2}$, Ford Lumban Gaol $^{3}$, Betty Purwandari ${ }^{4}$ \\ ${ }^{1,2,3}$ Doctor of Computer Science, Binus University; Jakarta 11530, Indonesia \\ ${ }^{4}$ Faculty of Computer Science, Universitas Indonesia, Depok 16424, Indonesia
}

\begin{abstract}
Digitalization in the financial sector challenges banking institutions to develop new methods of innovation processes by incorporating current concepts such as design thinking (DT), agile software development (ASD), and cocreation. This qualitative study is based on empirical research conducted at three Indonesian banks. Semi-structured interviews with three IT executives and a questioner of 31 middle managers participating in digital banking efforts were used to gather data. A Systematic Literature Review based on Kitchenheim processes generates keywords in the VOS Viewer software. NVIVO 12 qualitative software is employed to aid data analysis for illustrating the process integration. The research's contribution is identified, including process integration, obstacles, potential solutions, and enhanced framework on adopting DT, ASD, and Co-creation.
\end{abstract}

Keywords - design thinking, agile software development, co-creation, Innovation

\section{INTRODUCTION}

Digital technology influences every industry. Established bank institutions are under pressure to accelerate rapid innovation management and find new ways to enhance customer value to compete with start-ups and fintech firms. The question always seems to be: can incumbents do enough to survive? [1] The root cause of the banking innovation is that old-fashioned banks are far behind the latest technological breakthroughs[2]. Incumbent banks face a crucial challenge as they need to embrace digitalization and initiate a significant digital transformation of their business and operating models, which will overcome all kinds of constraints [3].

Due to digital banking's potential, bank institutions invest in digital banking to obtain substantial benefits and stay competitive with the digitalization era's challenges.
Various technologies and initiatives have arisen, and the digital banking application becomes more intelligent and personalized. Emerging technologies accelerate digital banking innovation, such as Artificial Intelligence, blockchain, cloud computing, and data science [4]. Several banking institutions in Indonesia adopt modern concepts and frameworks [5]. The motivation for this adoption is to reach efficiency in digital product development and achieve more high-quality digital banking platforms. However, the bank executives may be unsure how to adapt these concepts over a short period or how to choose which the most appropriate approach for their institution. The research investigates the adoption of three concepts in digital banking innovation: design thinking (DT), agile software development (ASD), and co-creation. Three organizations are involved and provide comprehensive insights into the adoption of the concept. The objective of the study is to answer the research questions:

RQ1 How does banking integrate agile software development with design thinking and co-creation in the digital banking innovation?

RQ2 What are the impacts of adopting the concepts on the performance of digital banking innovation?

RQ3 What are the challenges of adapting the concepts experienced by the banks and the potential solutions recommended towards digital banking innovation success?

\section{BACKGROUND}

\section{A. Overview of Digital Banking}

The rise of digital banking started with ATMs launched in the mids 1970s. The ATM story is a landmark study in digital banking innovation. 


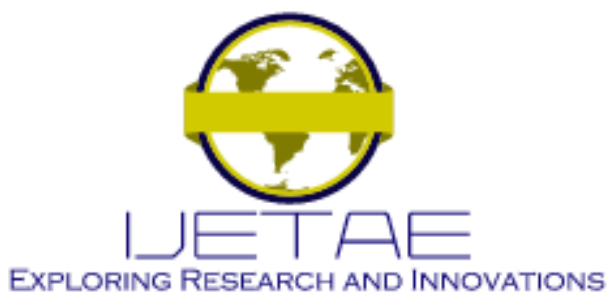

International Journal of Emerging Technology and Advanced Engineering

Website: www.ijetae.com (E-ISSN 2250-2459, Scopus Indexed, ISO 9001:2008 Certified Journal, Volume 12, Issue 01, January 2022)

Massachusetts Institute of Technology, in the "Digital Banking Manifesto: The End of Banks," divided digital banking innovation into three waves: (i) The first wave companies: the "incrementalists." In this category, the bank's main traditional banking methods and experience the incremental development of digital banking, from ATM in the 1970s to internet banking in 1996 (ii) Second wave companies: digital hybrids. These banks represent a bridge solution between traditional banks and fully digital banking. (iii) Third-wave companies: digital natives, the banks in this category were born in the digital era. The bank adopts new data technology and mobile telecommunication [2].

The future of Digital Bank (DB) as a result of the existing bank's unsatisfactory status presents unique prospects to create a digital bank from the ground up.
This type of bank will achieve its goals by utilizing cutting-edge technology such as cryptography, blockchain, artificial intelligence, big data, and deep learning. This bank will be very efficient, profitable, and agile [2]. Digital channels will become increasingly important in developing loyalty and driving growth for financial institutions as the internet and mobile banking penetration grows [6]. This study focuses on the new challenges in transforming the organization faced by traditional, non-digital native banks. Bankers must keep up with the fast pace of change in today's banking landscape. Banks must become more agile, adaptable, and dynamic in reaction to changes in technology and customer behavior. The bank should identify new ways of working to adopt and implement new technologies.

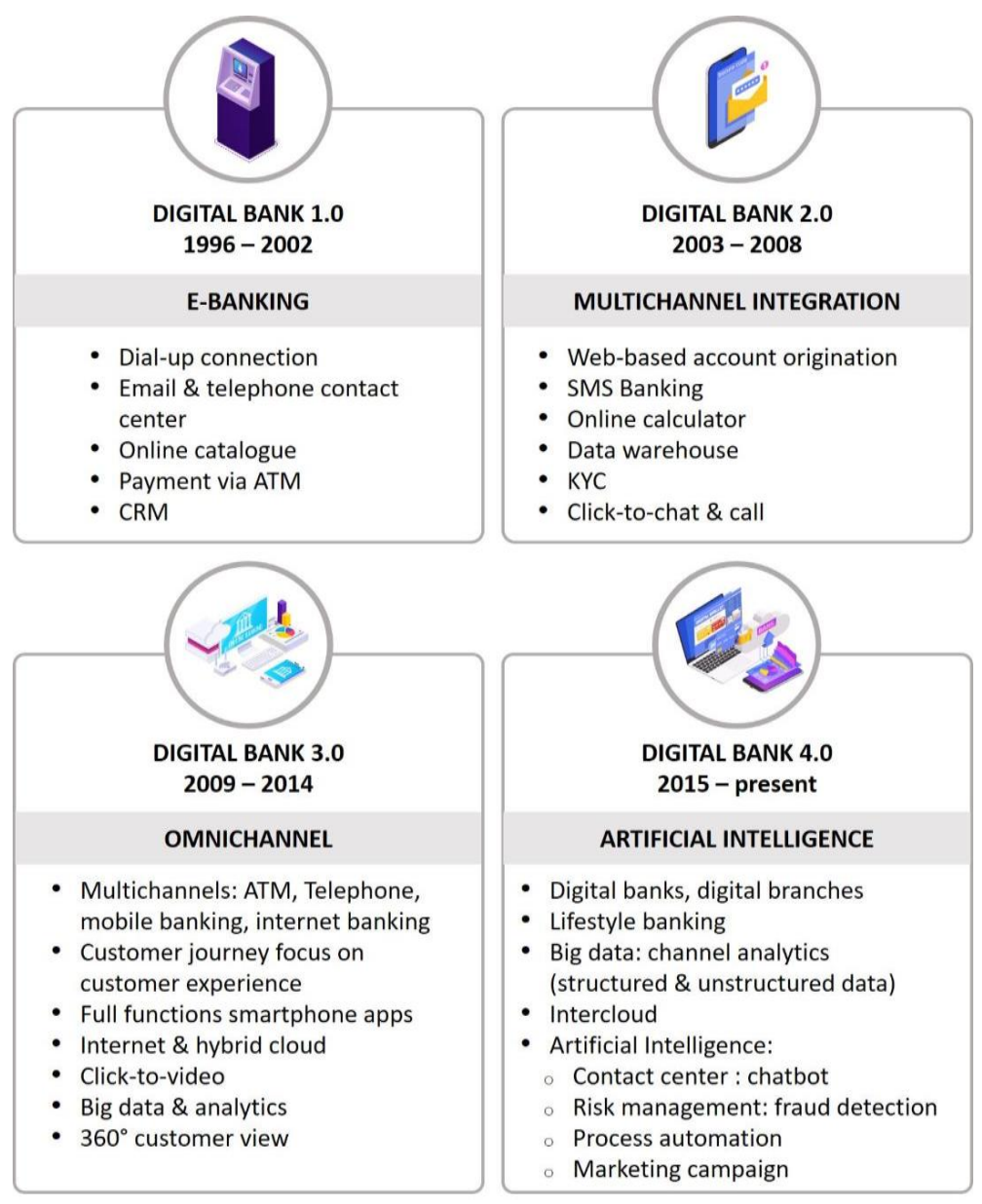

Figure 1. Digital Banking Evolution in Indonesia. Source: Author. 


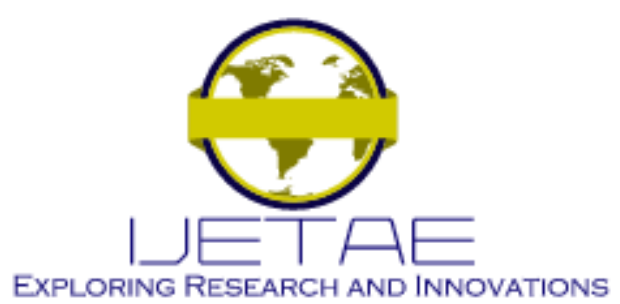

International Journal of Emerging Technology and Advanced Engineering

Website: www.ijetae.com (E-ISSN 2250-2459, Scopus Indexed, ISO 9001:2008 Certified Journal, Volume 12, Issue 01, January 2022)

\section{B. Overview of the Digital Banking in Indonesia}

The digital banking revolution in Indonesia started in the early 2000s when Indonesian banks began implementing internet banking and mobile banking. The technology trend adopted by the banking industry changes from time to time. Since 2010, shifting banking transaction patterns have been evident. Previously, transactions through branches, ATMs, and EDCs still dominated. However, with the development of digital banks, the number of traditional branches, ATMs, and EDCs has decreased. Banking transactions have begun to switch to online banking through internet banking or mobile banking. Figure 1 represents digital banking evolution in Indonesia.

\section{The Concept of Design Thinking}

One approach that is increasingly appealing to businesses of all sizes is design thinking [7]. DT has attracted both practitioners and academics since the early 2000s, and it offers new approaches to problem-solving and increased innovation capabilities. There is no consensus on a standard definition of DT. One of the pioneers of DT, Tim Brown, suggests that design thinking refers to "a discipline that uses a designer's sensibility and methods to match people's needs with technological feasibility, business strategy, and transforming it into customer value and market opportunity" [8].

Addressing the social dimensions of digital banking has recently become a critical competitive factor for banks. More user-centered and non-technical parts of design difficulties should emphasize digital banking advances. Design thinking has been discussed and applied as a new design paradigm for digital banking innovation. By improving the user experience, DT positively impacts customer relationships and adds to the bank's business model [9].

Table 1.

The most widely used models of design thinking [6]

\begin{tabular}{ll}
\hline \multicolumn{1}{c}{ Proponent } & \multicolumn{1}{c}{$\begin{array}{c}\text { Main stages of Design } \\
\text { Thinking }\end{array}$} \\
\hline IDEO & $\begin{array}{l}\text { Inspiration, ideation, } \\
\text { implementation }\end{array}$ \\
\hline $\begin{array}{l}\text { Stanford Design } \\
\text { School }\end{array}$ & $\begin{array}{l}\text { Empathy, define, ideate, } \\
\text { prototype, and test }\end{array}$ \\
\hline IBM & $\begin{array}{l}\text { Understand, explore, prototype, } \\
\text { evaluate }\end{array}$ \\
\hline
\end{tabular}

\section{The Concept of Agile Software Development}

For decades, software engineering circles have debated how to structure software development to offer faster, better, and lower-cost solutions [10]. Different types of projects necessitate different procedural models in order to be completed successfully. A procedural model organizes project management methodologies and technologies into defined project phases or procedures. Procedural models for project management can be split into two categories: (1) plan-driven methods, which follow a classical waterfall process, a sequential (non-iterative) process.; and (2) agile methodologies, which follow an iterative, test-driven approach [11]. Several alternative agile software development process models have emerged as a result of decades of research and practice. Many agile techniques have been developed, including crystal methodologies, dynamic software development method (DSDM), extreme programming, scrum, lean software development, and feature-driven development [10]. Agile software development's main objective is to generate quality software products cost-effectively through a series of short iterative and incremental development cycles [12]. Having originated in software development [11], agile software development is used in many industries, including for developing digital banking platform [13].

\section{E. The Concept of Co-creation}

Value creation in the digital age has become value cocreation between firms and customers [14]. Co-creation arises from the new paradigm involving customers as stakeholders in designing and developing products and services to suit customer personalities. The term value cocreation was introduced by Prahalad and Ramaswamy, who argued that there is a need for a new type of consumer to design their own experiences. Prahalad and Ramaswamy developed the DART model to explain the process of cocreation through its essential building blocks: dialogue, access, risk assessment, and transparency [15]. Stickdorn \& Schneider defines co-creation as a core aspect of its service design philosophy. It can involve staff, designers, executives, or customers working collaboratively to identify needs and innovate service experiences [16]. Gomillion has developed the concept of co-creation in the context of Information Systems. Co-created information systems define a system where developers and end-users perform a significant portion of the development [17]. Digital co-creation is distinct from the previous result of Information Systems research when examined on three dimensions. 


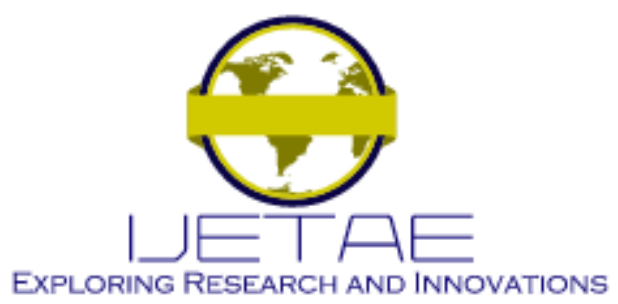

International Journal of Emerging Technology and Advanced Engineering

Website: www.ijetae.com (E-ISSN 2250-2459, Scopus Indexed, ISO 9001:2008 Certified Journal, Volume 12, Issue 01, January 2022)

First, end-user involvement in developing digital products will create better digital products that fit customer needs. Second, the end-user involved in co-creation is responsible for developing digital products with a scope of use across the organization. Third, the end-user creates a unique partnership between the end-user developers and Information System professionals [17]. The concept of cocreation in the context of digitalization has two approaches. First, the adoption of digital co-creation tools for improving team collaboration. Moreover, digital co-creation enables multiple stakeholders to co-create wherever and whenever [18]. The second method is to use big data to connect businesses and customers to promote value co-creation. It also includes the use of social media, which enhances cocreation's effectiveness and efficiency by lowering the cost of interaction among participants and allowing a more significant number of participants to contribute to a particular co-creation initiative [19].

\section{Methodology}

This study used the methodology listed below, represented in Figure 2.

First stage. The bibliographic research. Relevant literature is analyzed to identify state of the art, and the Kitchenhaim procedure was applied.
The result will be mapped using VOS Viewer software to see the relationship among the concepts.

Second stage. The semi-structured interview was selected as the primary data collection method because open questions can explore problems in-depth and in detail. The interview was performed using video conference in accordance with the health protocols caused by the pandemic situation. 3 IT Executives from 3 banks were invited for the online interview.

Third stage. The questionnaire was chosen to collect data from 31 middle managers to explore the operational level practice.

Fourth stage. Result and analysis. The study uses qualitative methodology. Qualitative research is interpretative research, and the re-searcher typically involves participants sustained and intensive experience [20]. There was no exact number or range of samples that could guide researchers for sample size in qualitative research. However, Ritchie proposed the qualitative sample often lies under 50 [21]. The researcher compiled the transcribed interviews and notes using NVivo 12 software in this stage.

Fifth stage. Recommendation and conclusion
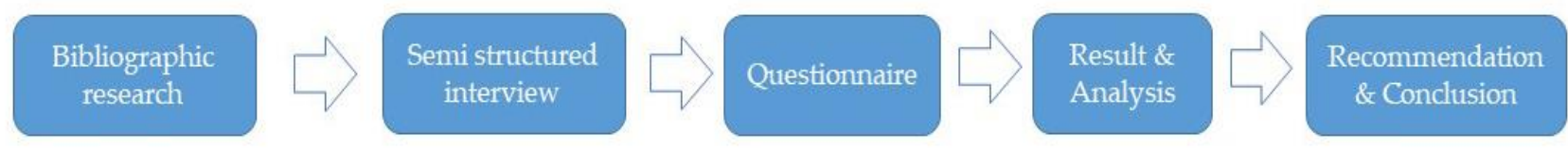

Figure 2. Research process. Source: Author

\section{LITERATURE REVIEW}

A comprehensive literature review was conducted using Kitchenhaims protocols for investigating the possibility of combining design thinking, agile software development, and co-creation concepts adoption in the digital banking innovation [22].

\section{A. The SLR Process Method}

The selection of articles was carried out in different stages using Kitchenham's SLR procedures, as follows:

1. Stage 1: Search process, including search strings and other criteria. In the search process, we looked at six popular databases as data sources: ACM, Emerald Insight, IEEE Xplore, AIS, Science Direct, and SpringerLink.
The most recent publications in international journals and international proceedings published between January 2015 and July 2021 were included in this search. For this purpose, the search terms used were ("design thinking" OR "agile software development" OR "cocreation" OR "integrate design thinking agile software development banking") AND (combine design thinking agile software development co-creation banking).

2. Stage 2: inclusion and exclusion criteria. The review has included only those research articles, which have been published since 2015. Only publications published in journals indexed in Scopus were chosen to ensure quality and the paper's impact on the studies. 


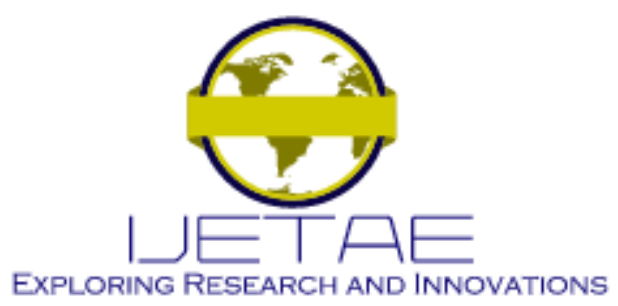

International Journal of Emerging Technology and Advanced Engineering

Website: www.ijetae.com (E-ISSN 2250-2459, Scopus Indexed, ISO 9001:2008 Certified Journal, Volume 12, Issue 01, January 2022)

3. Stage 3: Paper selection. In this stage, all the research articles produced from the automated and manual searches were individually evaluated after investigating their titles and abstracts.

4. Stage 4: Final review. After reading their full texts at this stage, we excluded several articles and rendered them ineligible for the SLR. Subsequently, the abstracts of the remaining articles were appraised based on the inclusion criteria. The methods and discussion portions of the paper were analyzed and summarized whether it was still relevant under the criteria.

\section{B. Selection of Primary Studies}

The SLR was conducted using a search string applied in some electronic databases. The outcome was 20 publications filtered by reading the titles, abstracts, and keywords. The application of this filter led to 10 publications being selected. Another filter was implemented based on the research's established inclusion and exclusion criteria. Five publications were classified for data extraction after these filters were applied. Beyond this, the search strategy involved using a manual search that generated 50 publications and, after applying the previous filters, including a complete reading, selected 40 publications. Thus, after executing an automatic and manual search (snowballing), we decided 25 papers to answer the research questions. Figure 3 compiles the results obtained during data collection. Table 2 shows the result of the literature review.

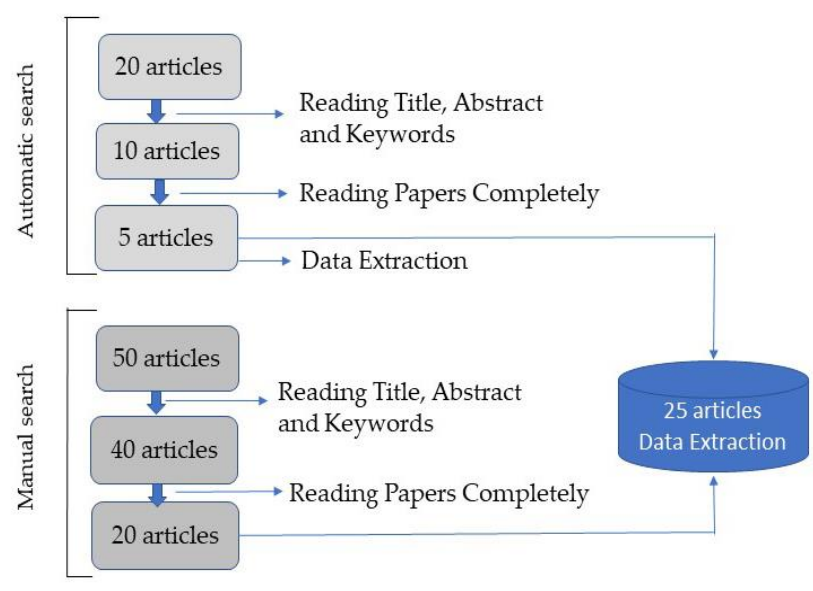

Figure 3. Articles selected from the Systematic Literature Review
Table 2.

Systematic Literature Review selected articles

\begin{tabular}{|c|c|c|}
\hline ID & Title & Reference \\
\hline $\mathrm{S} 1$ & $\begin{array}{l}\text { Key strategies for the successful involvement of } \\
\text { customers in the co-creation of new } \\
\text { technology-based services }\end{array}$ & [23] \\
\hline $\mathrm{S} 2$ & $\begin{array}{l}\text { Digital Transformation in Banking: Exploring } \\
\text { Value Co-Creation in Online Banking } \\
\text { Services in India }\end{array}$ & [24] \\
\hline S3 & $\begin{array}{l}\text { Combining Design Thinking and Agile } \\
\text { Development to Master Highly Innovative IT } \\
\text { Projects }\end{array}$ & {$[25]$} \\
\hline ID & Title & Reference \\
\hline $\mathrm{S} 4$ & $\begin{array}{l}\text { Integrated approach to the agile development with } \\
\text { Design Thinking in an industrial environment }\end{array}$ & [26] \\
\hline S5 & $\begin{array}{l}\text { An Integrated Framework for Design Thinking } \\
\text { and Agile Methods for Digital Transformation }\end{array}$ & {$[27]$} \\
\hline S6 & $\begin{array}{l}\text { The Use of Design Thinking for Requirements } \\
\text { Engineering }\end{array}$ & {$[28]$} \\
\hline S7 & $\begin{array}{l}\text { Coupling Design Thinking, User Experience } \\
\text { Design and Agile }\end{array}$ & [29] \\
\hline $\mathrm{S} 8$ & $\begin{array}{l}\text { Innovating Information System Development } \\
\text { Methodologies with Design Thinking }\end{array}$ & {$[30]$} \\
\hline S9 & $\begin{array}{l}\text { Design principles for digital value co-creation } \\
\text { networks: a service-dominant logic } \\
\text { Perspective }\end{array}$ & {$[31]$} \\
\hline S10 & $\begin{array}{l}\text { Exploring consumers' motivations to engage in } \\
\text { innovation through co-creation activities }\end{array}$ & {$[32]$} \\
\hline S11 & $\begin{array}{l}\text { Consumer Co-creation in New Product } \\
\text { Development }\end{array}$ & {$[33]$} \\
\hline $\mathrm{S} 12$ & $\begin{array}{l}\text { Managing Co-creation Design: A Strategic } \\
\text { Approach to Innovation }\end{array}$ & {$[34]$} \\
\hline S13 & $\begin{array}{l}\text { Design Thinking and Agile Practices for Software } \\
\text { Engineering: } \\
\text { An Opportunity for Innovation Design Thinking } \\
\text { and Agile Practices for Software Engineering. }\end{array}$ & {$[35]$} \\
\hline $\mathrm{S} 14$ & $\begin{array}{l}\text { Doing Design Thinking: Conceptual Review, } \\
\text { Synthesis, and Research Agenda }\end{array}$ & {$[5]$} \\
\hline S15 & $\begin{array}{l}\text { Reframed Contexts: Design Thinking for Agile } \\
\text { User Experience Design }\end{array}$ & {$[36]$} \\
\hline S16 & $\begin{array}{l}\text { Using Digital Co-creation For Innovation } \\
\text { Development }\end{array}$ & {$[18]$} \\
\hline S17 & $\begin{array}{l}\text { Value co-creation through social media: A case } \\
\text { study of a start-up company }\end{array}$ & {$[37]$} \\
\hline S18 & $\begin{array}{l}\text { How established companies leverage co-creation } \\
\text { insight from banking }\end{array}$ & {$[38]$} \\
\hline S19 & $\begin{array}{l}\text { Design Thinking Use in Agile Software Projects: } \\
\text { Software Developers' Perception }\end{array}$ & [39] \\
\hline S20 & $\begin{array}{l}\text { Knowledge-based New Product Development: } \\
\text { fostering innovation through knowledge co- } \\
\text { creation }\end{array}$ & [40] \\
\hline
\end{tabular}




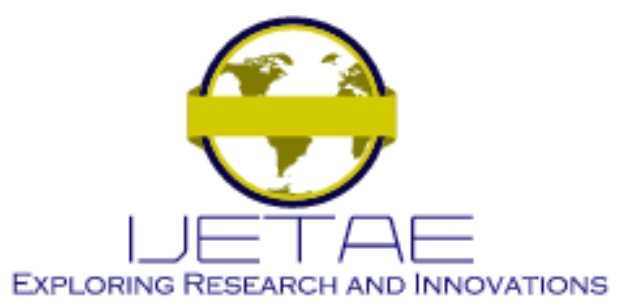

International Journal of Emerging Technology and Advanced Engineering

Website: www.ijetae.com (E-ISSN 2250-2459, Scopus Indexed, ISO 9001:2008 Certified Journal, Volume 12, Issue 01, January 2022)

\begin{tabular}{|l|l|c|}
\hline S21 & $\begin{array}{l}\text { Design Thinking: Challenges for Software } \\
\text { Requirements Elicitation }\end{array}$ & {$[41]$} \\
\hline S22 & $\begin{array}{l}\text { DT@ Scrum: Integrating Design Thinking with } \\
\text { Software Development Processes }\end{array}$ & {$[42]$} \\
\hline S23 & $\begin{array}{l}\text { The Use of Design Thinking in Agile Software } \\
\text { Requirements Survey: A Case Study }\end{array}$ & {$[12]$} \\
\hline S24 & $\begin{array}{l}\text { Contributions of Design Thinking to Project } \\
\text { Management in an Innovation Context }\end{array}$ & {$[43]$} \\
\hline S25 & $\begin{array}{l}\text { From Social Media to Social Product } \\
\text { Development: The Impact of Social Media on Co- } \\
\text { Creation of Innovation }\end{array}$ & {$[44]$} \\
\hline
\end{tabular}

\section{Systematic Literature Review Results}

After performing a Systematic Literature Review using Kitchenhaim procedures, 25 papers were analyzed using VOSViewer for mapping the relationship between the concepts. Figure 4 shows the map of the relationship among design thinking, agile software development, and co-creation using VOSViewer software.

Based on the map of the relationship represented in Figure 4, we conclude that based on the academic literature, the practice of the concepts identified as follow:

1. DT, ASD, and co-creation are utilized to support the innovation process in the organization.

2. DT, ASD, and co-creation are adopted to support product development practice.

3. The agile method, integration to DT, and co-creation practice can improve customer value in the organization.

Figure 5 represents the integration of the concept based on the systematic literature review. The conceptual framework highlights three main concepts: Agile Software Development (Agile Manifesto, 2001), Design Thinking (Brown, 2008), and Co-creation (Prahalad, 2004). Agile methods have become popular in the software development. While they are effective at implementing solutions, they are unable to determine what should be implemented. This is especially problematic for complex innovation projects such as digitization efforts in which the exact project goal is not yet known. To overcome this problem, several researchers have proposed following a design upfront approach using the design thinking methodology [25][41].

When the design thinking concept integrates with the agile software development approach, comprehensive communication occurs between the software development team and customers [45].

Efforts to bring design thinking into software systems development are not limited to user interface and end-user interactions. Still, they need to go far beyond that. The design thinking adoption creates values principles. Developers and UI/UX designers are frequently involved in design activities while working on digital platforms. Design thinking techniques tools are utilized for brainstorming, sketching, and prototyping. In contrast, agile software development techniques tools are used for testing, continuous integration, pair programming, and refactoring [46].

Most of these co-creation studies have been undertaken since 2004 [17]. The prior co-creation study focuses on marketing and management [15] [47] [48]; but the concept of digital co-creation was introduced in 2016 [18]. However, in 2020, when the Covid-19 pandemic appeared, the digital co-creation concepts started to be implemented massively. Because the pandemic impacts the way people work, people could not come to the office to collaborate face-to-face, all project initiatives were conducted remotely. As a result, online collaboration tools have been adopted rapidly. Observing the phenomena, the researcher agrees with the prior researcher in combining the concepts of DT and ASD [25] [41] [27], also promoting the cocreation concept for integration with new digital product development.

However, we know that the implementation of these concepts is not easy. It is possible that design thinking and agile software development are only appropriate for specific companies and might not be the ultimate solution for others firms. The first reason is that design thinking concepts created through collaboration with customers can be complex. The general concern about DT is that far too much time is spent comprehending the problem before the development process can begin. The general criticism of DT is that it spends way too much time understanding the problem before beginning the development process. When a project is time-constrained, DT's feasibility is harmed. [27]. For example, the iteration process will consume resources and time while performing wireframes and prototyping. The second reason is that Agile methods were initially designed for small, single-team projects [49]. It will be a challenge for high-regulated and giant corporations with complex organization structure to adopt it. Further, the study will provide the basis for envisioning and evaluating possible solutions. 


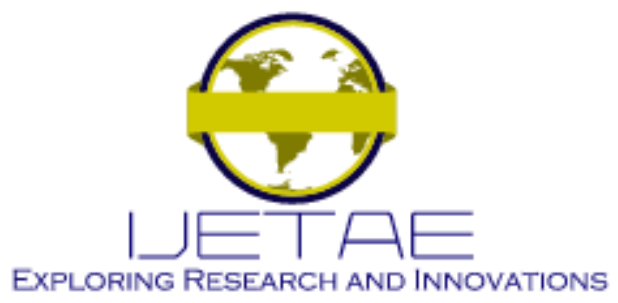

International Journal of Emerging Technology and Advanced Engineering

Website: www.ijetae.com (E-ISSN 2250-2459, Scopus Indexed, ISO 9001:2008 Certified Journal, Volume 12, Issue 01, January 2022)

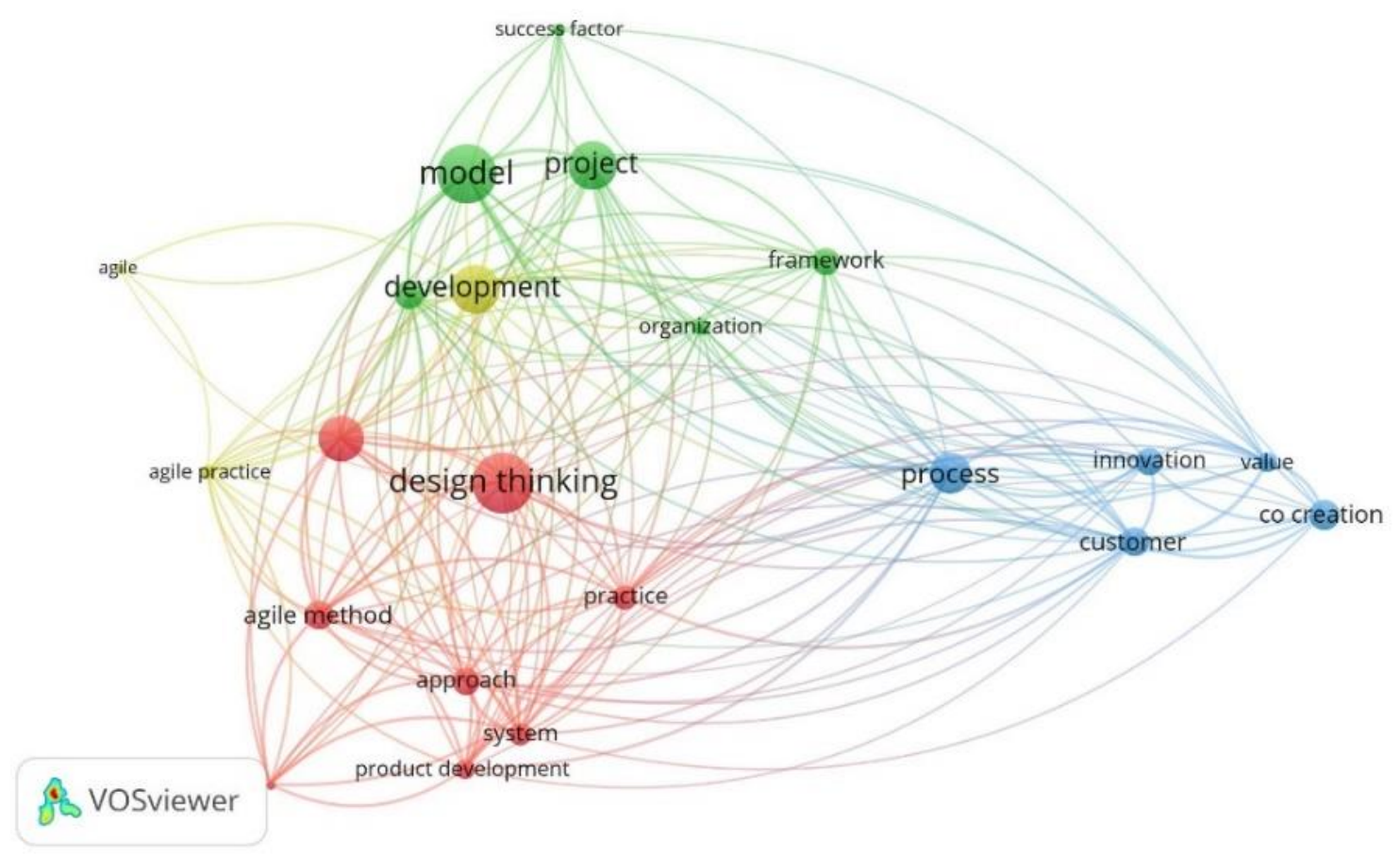

Figure 4. The map of the relationship among design thinking, agile software development, and co-creation.

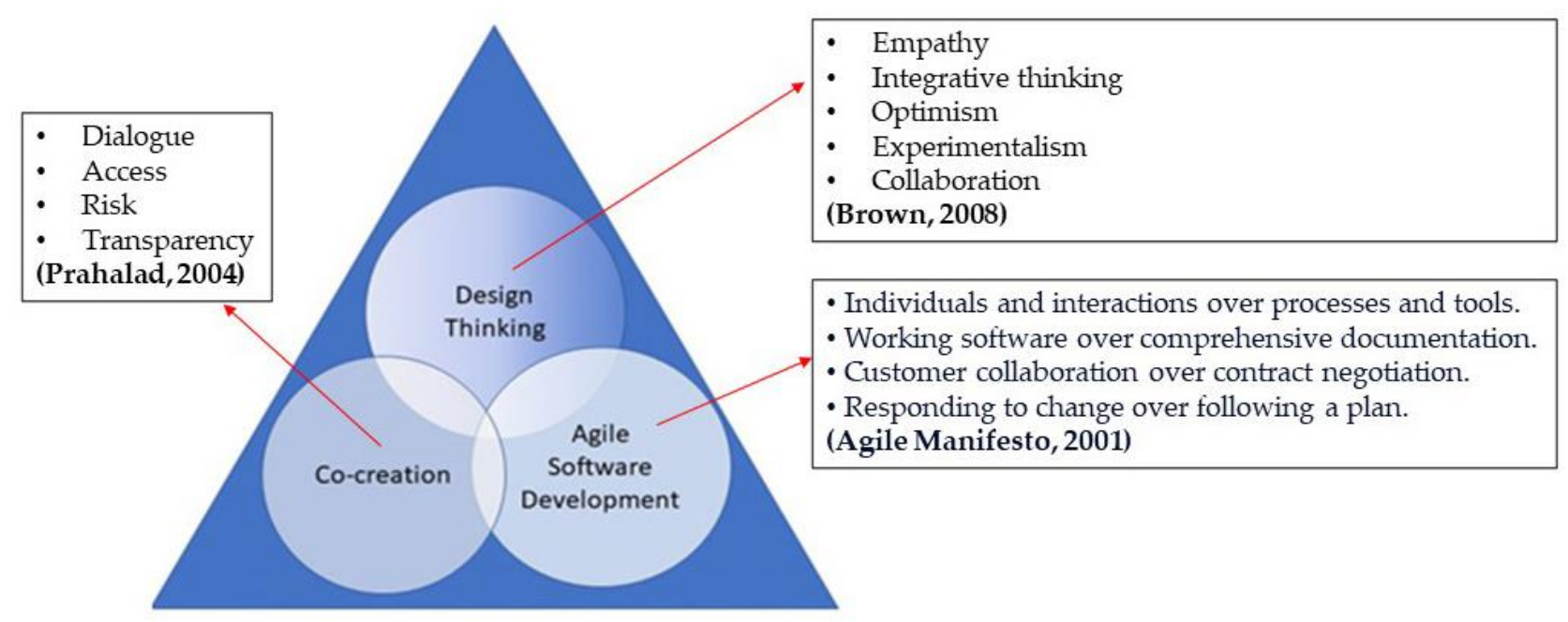

Figure 5. Conceptual Framework 


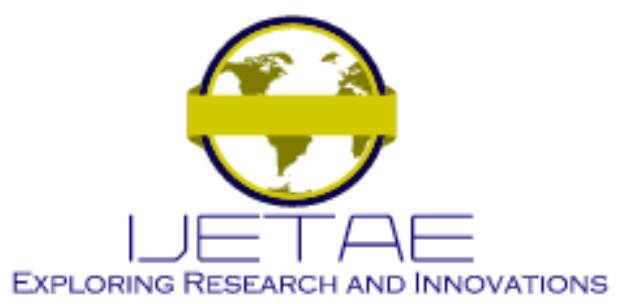

International Journal of Emerging Technology and Advanced Engineering

Website: www.ijetae.com (E-ISSN 2250-2459, Scopus Indexed, ISO 9001:2008 Certified Journal, Volume 12, Issue 01, January 2022)

\section{CASE Study: Digital Banking INNOVATION USING DT, ASD, AND CO-CREATION IN INDONESIA}

This study takes a multi-case approach to investigate digital banking innovation in Indonesia.A case study research enables researchers to conduct in-depth investigations of a phenomenon of interest over a period of time, which is currently lacking in the literature on adoption of DT, ASD, Co-creation.
Multi-case studies are preferable to single-case studies because the results gained from multiple case studies are more powerful than those drawn from a single case study. This argument is the primary motivation behind selecting multiple case studies as the research method. An overview of study participants is provided in Table 3. Several interviews were conducted with key people involved in digital banking innovation from July 1 to September 1, 2021

Table 3

Focus Group Discussion Participants

\begin{tabular}{|ccclll|}
\hline No & Company & Ownership & Participants & Main concepts adoption & Assets \\
\hline 1 & Bank A & State-owned bank & Senior Vice & $\sqrt{ }$ Design Thinking & IDR 1.318 trillion \\
& & & President Digital & $\sqrt{ }$ Agile Software Development & \\
& & & Banking & $\sqrt{ }$ Co-creation & \\
\hline 2 & Bank B & Private bank & Vice President & $\sqrt{ }$ Design Thinking & IDR 193,5 trillion \\
& & & Digital Banking & $\sqrt{ }$ Agile Software Development & IDR 141.641 trillion \\
\hline 3 & Bank C & Private bank & Vice President & $\sqrt{ }$ Design Thinking & \\
& & & Digital Banking & $\sqrt{ }$ Agile Software Development & \\
& & & & $\sqrt{ }$ Co-creation & \\
\end{tabular}

Source: Annual Report, 2022

Case 1. Bank A Bank A is a state-owned bank, and the bank is one of the biggest total assets in Indonesia. As a highly regulated company, the bank faces the challenges of an increasingly digital world. The bank decided to build digital capabilities by reducing dependency on IT vendors and recruiting new digital talents. In 2019, the digital banking delivery group was created to improve its capacity to innovate. The adoption of design thinking, agile software development, and co-creation concepts started in 2019. Two hundred employees are involved in developing digital banking products.

Case 2. Bank B is a private bank. Bank B presents a comprehensive range of digital banking services, including mobile banking, online banking, SMS banking, and online banking. The bank also aims to adopt the latest technology, such as blockchain and Artificial Intelligence. The bank collaborated with International partners to develop the digital banking ecosystem. By focusing on digitalization in the business sector, the banks can optimize the service for the customers. Currently, Bank B has adopted design thinking and agile software development but has not considered co-creation adoption.
The bank management still does not involve the customers in developing digital banking since they are concerned about security and confidentiality issues.

Case 3. Bank $\mathrm{C}$ is a private bank. The bank continues to accelerate the development of digital platforms to create a seamless and integrated online and offline experience. The branch model is directly connected to all digital services owned by the bank, namely super apps related to mobile banking, API banking, Internet Banking, Corporate Banking, Digital Value Chain, Voice ID Call Centers, ATMs, and social media. Bank $\mathrm{C}$ has adopted design thinking and agile software development. The bank management still does not involve the customers in developing digital banking since they are concerned about security and confidential issues. Still, the bank uses the cocreation concept by performing social media data analytics.

For the survey, the selected experts are thirty-one senior managers from three banks in Indonesia who are involved in developing digital banking. 


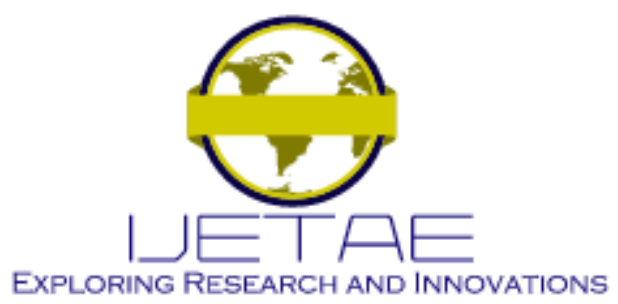

International Journal of Emerging Technology and Advanced Engineering

Website: www.ijetae.com (E-ISSN 2250-2459, Scopus Indexed, ISO 9001:2008 Certified Journal, Volume 12, Issue 01, January 2022)

Table 4.

The respondents of the survey

\begin{tabular}{|c|c|c|c|c|}
\hline Code & Job role & $\begin{array}{c}\text { Working } \\
\text { experience } \\
\text { (Year) }\end{array}$ & $\begin{array}{c}\text { Project } \\
\text { duration } \\
\text { (month) }\end{array}$ & $\begin{array}{c}\text { Total } \\
\text { team } \\
\text { (peoples) }\end{array}$ \\
\hline $\mathrm{P} 1$ & Scrum Master & 10 & 12 & 43 \\
\hline $\mathrm{P} 2$ & Scrum Master & 12 & 20 & 100 \\
\hline P3 & Back End Developer & 16 & 3 & 14 \\
\hline P4 & Team Leader & 11 & 3 & 70 \\
\hline P5 & Scrum Master & 17 & 4 & 15 \\
\hline P6 & Backend Developer Lead & 14 & 3 & 8 \\
\hline P7 & Front End Developer Lead & 14 & 24 & 100 \\
\hline P8 & Front End Developer Lead & 12 & 24 & 150 \\
\hline P9 & Backend Developer Lead & 10 & 18 & 50 \\
\hline P10 & Backend Developer Lead & 16 & 24 & 100 \\
\hline $\mathrm{P} 11$ & Scrum Master & 13 & 24 & 10 \\
\hline $\mathrm{P} 12$ & Backend Developer Lead & 12 & 6 & 5 \\
\hline P13 & Front End Developer Lead & 10 & 12 & 9 \\
\hline P14 & Agile Coach & 25 & 20 & 260 \\
\hline $\mathrm{P} 15$ & Backend Developer Lead & 20 & 6 & 4 \\
\hline P16 & Team Leader & 10 & 6 & 40 \\
\hline P17 & Team Leader & 10 & 6 & 40 \\
\hline P18 & Backend Developer Lead & 20 & 12 & 4 \\
\hline P19 & Product Owner & 21 & 6 & 20 \\
\hline $\mathrm{P} 20$ & Project support & 10 & 5 & 5 \\
\hline $\mathrm{P} 21$ & Scrum Master & 15 & 6 & 10 \\
\hline P22 & Business Analysist & 11 & 6 & 10 \\
\hline $\mathrm{P} 23$ & Scrum Master & 10 & 10 & 6 \\
\hline $\mathrm{P} 24$ & Team Leader & 12 & 12 & 10 \\
\hline $\mathrm{P} 25$ & Product Owner & 10 & 24 & 35 \\
\hline $\mathrm{P} 26$ & Product Owner & 15 & 6 & 17 \\
\hline $\mathrm{P} 27$ & Quality Assurance Team Lead & 10 & 4 & 30 \\
\hline $\mathrm{P} 28$ & Project Manager & 15 & 4 & 26 \\
\hline P29 & Product Owner & 10 & 24 & 35 \\
\hline $\mathrm{P} 30$ & Project Management Office & 24 & 38 & 30 \\
\hline P31 & Scrum Master & 10 & 8 & 20 \\
\hline
\end{tabular}




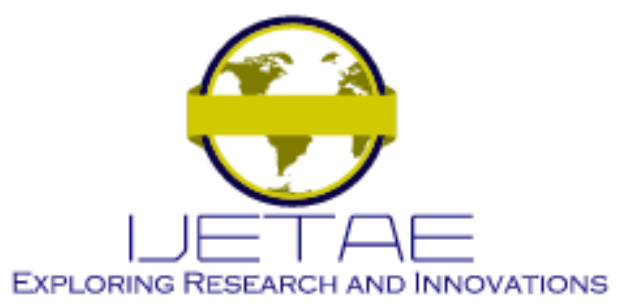

International Journal of Emerging Technology and Advanced Engineering

Website: www.ijetae.com (E-ISSN 2250-2459, Scopus Indexed, ISO 9001:2008 Certified Journal, Volume 12, Issue 01, January 2022)

\section{RESUlt AND ANALYSIS}

The following section reviews the detailed result and analysis of the digital banking case relative to the research question. This section describes how the adoption of digital innovation captured in our research framework is currently implemented in various digital banking innovation technology initiatives by the institutions involved in our study.

A. RQ1: How does banking integrate the Agile Software Development with Design Thinking and co-creation in the digital banking Innovation?

This section defines the concept of integration design thinking, agile software development, and the co-creation process. From the three institutions' business case, researcher highlighted that the digital innovation process's transition substantially depends on the executive management's leading role (Chief Technology Officer, Chief Information Officer).

The case study company understood the potential advantages of each central concept. They start the adoption by creating ground rules and building a comprehensive understanding of the concept and process to all stakeholders (team of developers, product owners, compliance, etc.). The IT executives' interview reflected that empirical evidence supports the applicability cocreation process in digital banking innovation. The cocreation process involves collecting customer pain points and wish list, building pre-hypothesis, doing research, and performing social media analysis. Figure 6. Illustrates the discovery phase using co-creation concepts in the digital banking innovation.

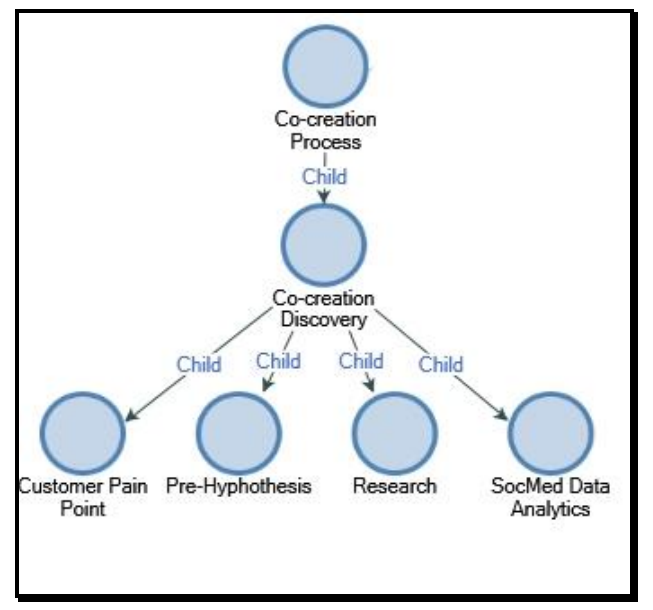

Figure 6. Co-creation process
Interviewee AT described the process of co-creation adoption in the digital banking innovation:

"At the beginning of digital banking initiatives, we are gathering the customer pain-point, then building a prehypothesis based on the customer pain point and wish list. Afterward, we engaged the co-creation team by informing them of the hypothesis. The co-creation team will build customer segments and product proposition communities. For example, we create a promotion and event for the millennial segment related to traveling. We asked the customers about their wish lists, ideal user journey, product, and features. We focus on listening to customer's aspirations or expectations about the ideal products and features".

Bank A involved the customers in identifying customer pain points and wish lists, also doing pre-hypothesis. Survey and focus group discussions were conducted to gather user requirements. Bank $\mathrm{B}$ and Bank $\mathrm{C}$ do not involve the customers in the development process. Bank B and Bank $\mathrm{C}$ use social media to interact with customers and conduct data analytics to understand customer behavior.

Interviewee AP describes the reason why not to involve the customer in the digital banking innovation:

"We did not involve the customers in the product development process because of security and regulation issues. To understand the customers' insight, we analyze social media and make predictions using big data analytics."

The interviewee AT response align with Schreieck et al., who confirm that IT's established value co-creation and openness can benefit the organization but needs to address specific conflict areas and potential benefits of balancing transparency and control and governing collaboration [38]. There is vast and growing potential for co-creating value with customers through interactive self-service technologies, such as digital banking platforms. However, there are significant dangers of value co-destruction [24]. Each organization needs to consider the co-creation adoption based on the company's specific situation, including the balancing between risk and potential benefits of co-creation.

Design Thinking is a method for determining what is technically and economically possible in order to better understand client needs. The DT approach generates solutions by providing better products and services and increasing productivity and operational improvements [50]. 


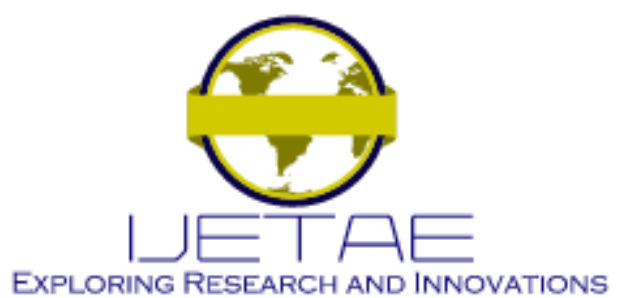

International Journal of Emerging Technology and Advanced Engineering

Website: www.ijetae.com (E-ISSN 2250-2459, Scopus Indexed, ISO 9001:2008 Certified Journal, Volume 12, Issue 01, January 2022)

Interviewee AT stated the process of design thinking in the digital banking innovation:

"The product team and UI/UX team will create a series of user stories and wireframes to illustrate the ideal products or features based on customer persona. Furthermore, after the wireframes get approval by the team leader and management, the team will work with the developers (front-end developer, back-end developer, etc.) for developing the digital banking platform".

Illustrating the design thinking process in the digital banking innovation, we develop node structure as shown in figure 7 .

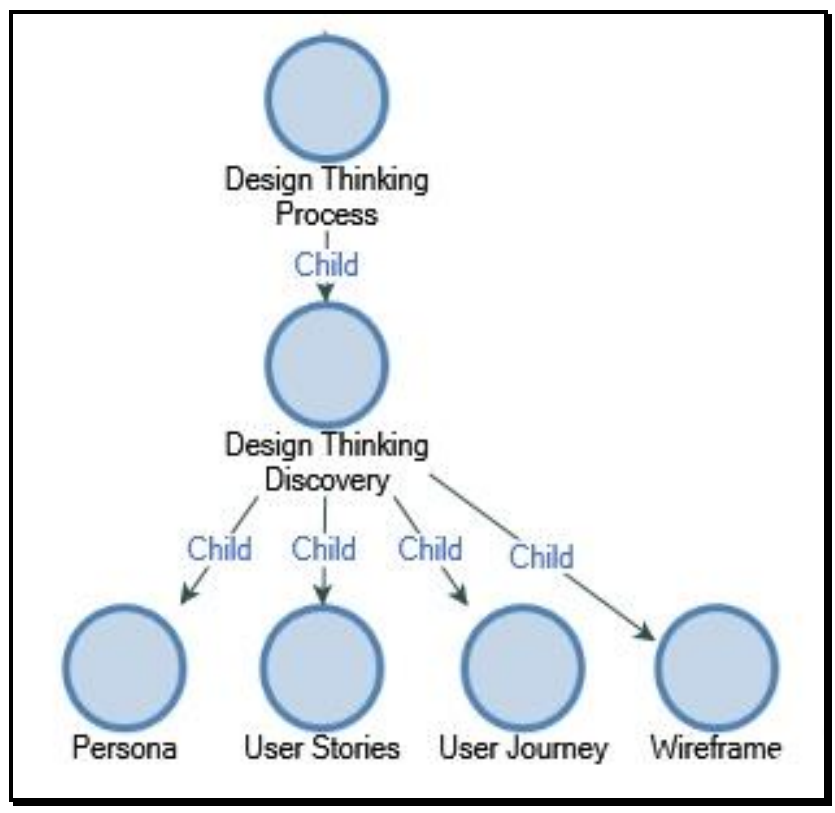

Figure 7. Design Thinking process

Bank $\mathrm{A}$ adopted design thinking in the discovery stage for collecting user requirements, and practicing DT tools, such as: (i) persona, (ii) user stories (iii) user journey, and (iv) wireframe. Bank A involved customers by inviting them as participants in Focus Group Discussion for brainstorming sessions. In Bank B and C, design thinking is performed internally, facilitated by product owners. Privacy and security become issues for involving the customers in the innovation process.
Agile practices have been demonstrated to increase project success [25]. A core aspect of agile methods in software development is reacting flexibly to changes. The appropriate implementation of the ASD can benefit the business by allowing for broad information interchange and favoring collaborator learning, resulting in increased pleasure, social skill development, frequent feedback, and professional trust. From the customer's perspective, the product's value, a better relationship with the customer, and higher product quality are the most apparent and significant benefits. Short iterations, continuous testing, selfmanageable teams, constant collaboration, and regular replanning based on reality rather than potentially obsolete plans are all ASD features [50].

The integration of concepts DT, ASD, co-creation can be complicated, but it will create more dialogue and collaboration between stakeholders in the development phase. So that, the outcome is the sophisticated features to reduce the possibilities of product failure from the customers' perspective

"We divided the agile software development process into four phases: discovery, planning, development, testing, and deployment. The team leader will approve the business requirement resulting from the discovery phase in the planning process. Afterward, we will arrange product backlogs. We will define features that we need to develop in the product backlog. In terminology, we call it epic. We will discuss the user story and ensure the flow is based on the epic. We identify not only the positive flow but also the negative flow. In the development phase, we perform prototyping and feature development. After, we perform testing, including UAT, coverage test, autometer test, and performance test. Once the digital application is ready, we deploy the digital application on the server."

\section{VK, Senior Vice President.}

Based on the interview with IT Executive to discuss about the process integration, we illustrate the Agile Software Development integration process in digital banking innovation as shown in figure 8 . 


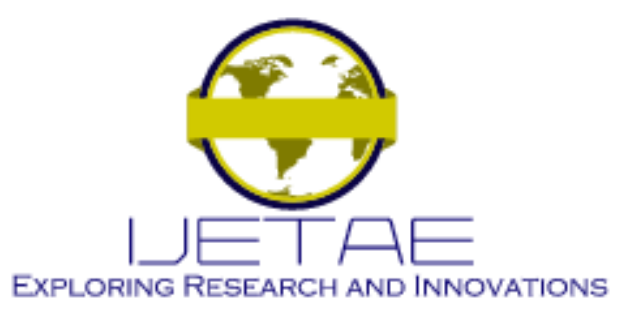

International Journal of Emerging Technology and Advanced Engineering

Website: www.ijetae.com (E-ISSN 2250-2459, Scopus Indexed, ISO 9001:2008 Certified Journal, Volume 12, Issue 01, January 2022)

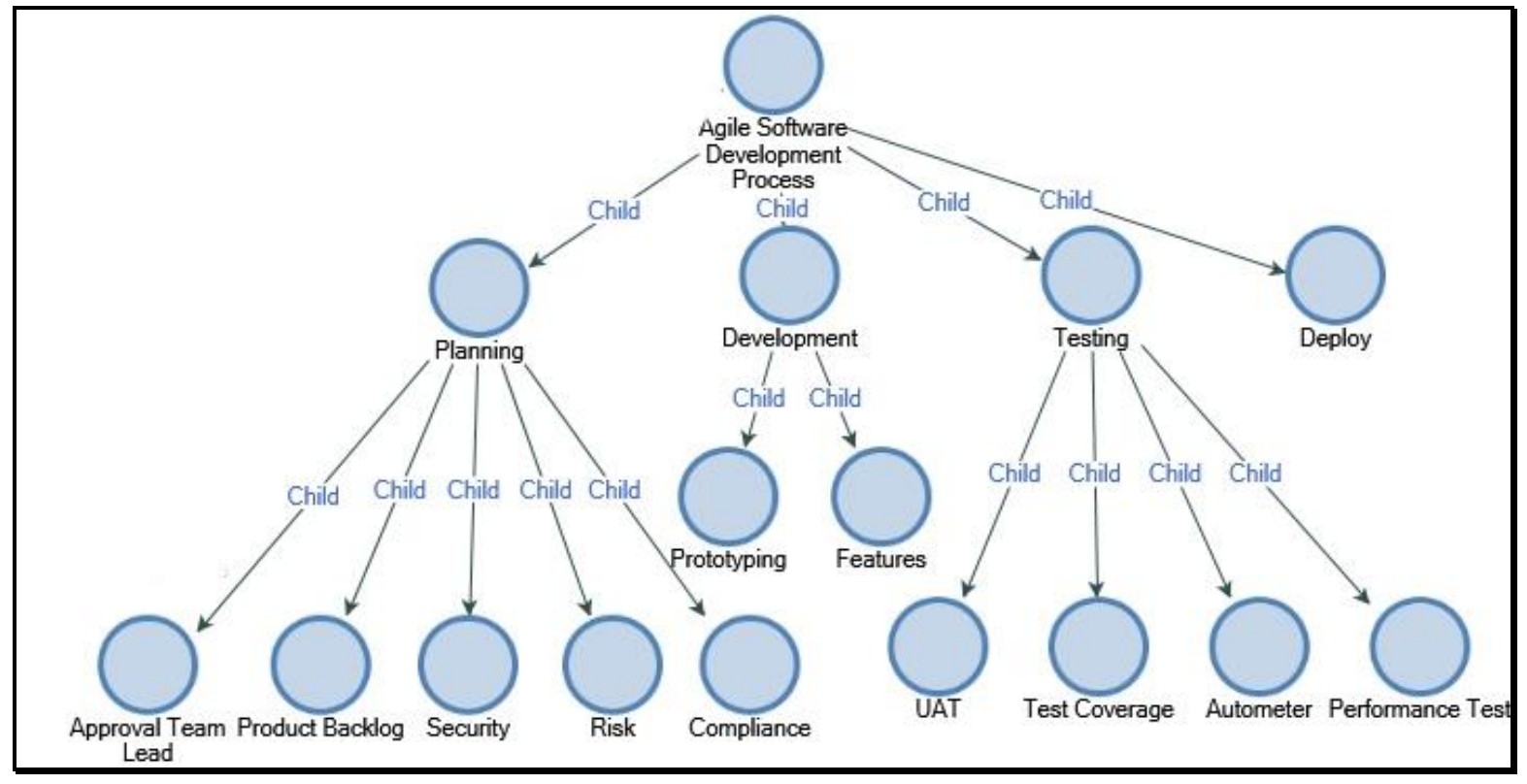

Figure 8. Agile Software Development process

B. RQ2: What are the impacts of adopting the concepts on the performance of digital banking innovation?

Based on the thematic content analysis to the interview transcripts with IT Executive, combining DT, ASD, Cocreation can impact the performance of the digital banking innovation as represented in Table 5.

Table 5.

Impacts and indicators of digital banking innovation Source: Author

\begin{tabular}{|l|l|}
\hline \multicolumn{1}{|c|}{ Impacts } & \multicolumn{1}{c|}{ Indicators } \\
\hline High-quality digital product & $\begin{array}{l}\text { Usage } \\
\text { Profitability }\end{array}$ \\
\hline Better customer experience & $\begin{array}{l}\text { Rating } \\
\text { Customer Satisfaction }\end{array}$ \\
\hline $\begin{array}{l}\text { Faster digital product } \\
\text { development and shorter time } \\
\text { to market }\end{array}$ & $\begin{array}{l}\text { Development cycle time } \\
\text { (time) }\end{array}$ \\
\cline { 2 - 2 } & $\begin{array}{l}\text { Deployment frequency / } \\
\text { rate (time) }\end{array}$ \\
\hline Reduce cost/budget & Cost/Budget \\
\hline Complete features & Customer Satisfaction \\
\hline
\end{tabular}

Based on the interview with IT Executives, we reveal the impact as follows:

\section{High-quality digital innovation outcomes}

Adopting DT, ASD, co-creation can produce a higher quality digital product, and it will increase usage and contribute to the organization's profitability.

\section{Better customer experience}

Adopting DT, ASD, and co-creation can improve customer experience. The banks involve customers in designing their journey for creating a better customer experience. The indicators being used are rating and customer satisfaction. The interviewees AP and AT believe that the rating cannot be used for rating since sometimes people can give fake comments and reviews. While VK still believes the rating can be used for reviewing the performance of the platform but needs to be investigated deeply by following up constantly with the respective customers who give the rating and comments.

\section{Faster digital product development and shorter time to market}

Adopting DT, ASD, and co-creation will reduce development cycle time. They highlight that the adoption can reduce the time for preparing the documentation. Hence, the developer can focus more on technical aspects. For evaluating the success of digital innovation projects and the development cycle time. 


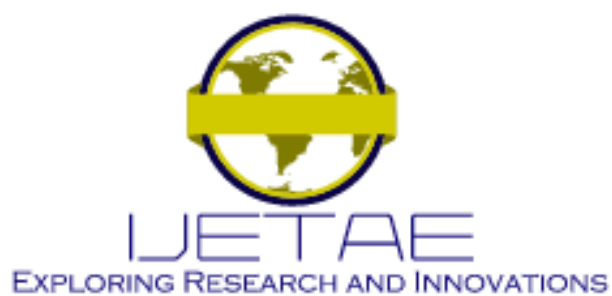

International Journal of Emerging Technology and Advanced Engineering

Website: www.ijetae.com (E-ISSN 2250-2459, Scopus Indexed, ISO 9001:2008 Certified Journal, Volume 12, Issue 01, January 2022)

\section{Reduce cost or budget}

Adopting DT, ASD, and co-creation will improve the efficiency of the digital banking innovation process. Launching the slight bite of the apps with the concept of Minimum Viable Product (MPV), can avoid the failure of the product. The management can review the customers' acceptance before developing into more prominent apps with complete features. It will reduce the banks for wasting investment funds failing the digital banking platforms.

\section{More customer-centric digital banking platform}

Adopting DT, ASD, and co-creation can create a customer-centric digital platform. The banks involve customers in the product development phase to gather complete features based on customers' preferences.

C.RQ3: What are the challenges experienced by the banking institutions and the potential solutions recommended towards the digital banking innovation success?

A multiple case study in 3 banks involving 31 developers revealed five challenges and the potential solution in integrating DT, ASD, and co-creation as illustrated in Table 7.

The result of the thematic analytics based on a questionnaire from thirty-one middle managers reveals that the most challenging factors in digital banking innovation is the "process." Challenges involved in the process include unclear requirements, requirement changes, transition, general rules and principles, timeline, agile ceremony, risk, business process, and quality. When user requirements are unclear and there are constant modifications during development, it becomes difficult to maintain knowledge about the code. A delay in the development stage will occur [39], affecting the quality and timelines. This can also create a risk to the organization in terms of budget and delivery time. Digital banking platform development is very complex with multiple agile teams. It is noticeable that there is no means of integration and synchronization versatile enough to suppress all problems during development.
The survey of 31 middle managers reveals that the organization needs to transition when adopting new concepts. The knowledge transfer of the general rules and principles to the stakeholders should be initiated first. Furthermore, the adoption of new concepts can impact the business process. Before adopting the new concepts, the organization should evaluate readiness to avoid failure in the implementation.

The organization's challenges include top management support, communication, structure, and culture. Top management plays a vital role in innovation. Banking organizations have an enormous organizational legacy and are considered less agile than start-up and innovation companies. So, the challenge to innovate lies in the structure and culture. In general, many organizations are resistant to change, sceptical towards the new way of working [49]. Communication becomes a barrier to collaboration among teams. Leaders must motivate people and spread the passion for common aims. The more each individual's personal goal is connected with the company's goals, the more influential the entire team's performance will be [51].

Actors and roles, human resources, and mentality are part of the people's challenge in digital banking innovation. Leaders must develop their teams' talent, abilities, and innovation regardless of the goals and plans they have set. They must encourage participation, which transforms each team member into a stakeholder who takes responsibility and contributes to the general success of the organization with their particular skills [51].

The technology challenges digital banking innovation. The participants in the survey mention that security is the central issue in digital banking innovation, while regulation becomes a crucial issue in the environment. Revelation from the IT Executives in Figure 8 show how, the banks performed planning related to security, compliance, and risk, even at the beginning of the project. These steps are important for prevention for the serious issues related to the privacy, security, and regulation. The potential solutions of digital banking innovation result from the literature review presented in Table 7. 


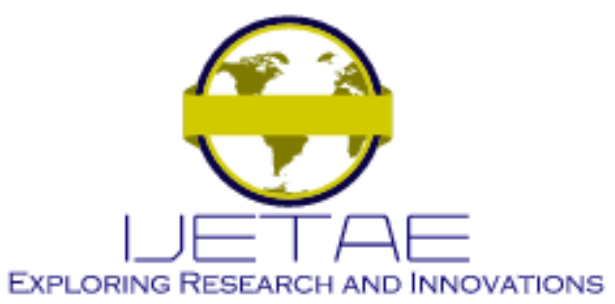

International Journal of Emerging Technology and Advanced Engineering

Website: www.ijetae.com (E-ISSN 2250-2459, Scopus Indexed, ISO 9001:2008 Certified Journal, Volume 12, Issue 01, January 2022)

Table 7.

Codes and themes on challenges of digital banking innovation

Source: literature review \& survey

\begin{tabular}{|c|c|c|}
\hline Category & Challenges & Potential solution \\
\hline 1. Technology & Security & $\begin{array}{l}\text { Investigate non-functional requirements: security [52], } \\
\text { Training potential users and stakeholders on security issues [42] }\end{array}$ \\
\hline \multirow[t]{4}{*}{ 2. Organization } & $\begin{array}{l}\text { Top management } \\
\text { support }\end{array}$ & $\begin{array}{l}\text { Company strategy, Problem statement, Advisory board involvement } \\
\text { in DT phase [25]. }\end{array}$ \\
\hline & Communication & $\begin{array}{l}\text { Regulation, output formats, reporting system, extensive planning } \\
\text { [42] }\end{array}$ \\
\hline & $\begin{array}{l}\text { Organization } \\
\text { structure }\end{array}$ & Minimum hierarchy [27] \\
\hline & Innovation culture & Digital vision, Product vision [25] \\
\hline \multirow[t]{9}{*}{ 3. Process } & Unclear requirement & $\begin{array}{l}\text { Market research, interviews, sketching [35], persona, product vision } \\
\text { [25], empathy map, storyboard [41], customer co-creation [39], } \\
\text { brainstorming, journey mapping [39], list of technical requirements, } \\
\text { prioritized list of detailed user stories [42] Learning Launch [39]. }\end{array}$ \\
\hline & Requirement change & Prototyping / Minimum Viable Product [41] [35] \\
\hline & Transition & Blueprint [41], Workshop [25] \\
\hline & $\begin{array}{l}\text { Guideline and } \\
\text { principles }\end{array}$ & Regulation: planning, output formats, reporting system [42]. \\
\hline & Timeline & Planning [42] \\
\hline & Agile ceremony & Sprint [35][39] \\
\hline & Risk management & Risk mitigation [52] \\
\hline & Business process & Backlog management [35], Project documentation [52] \\
\hline & Quality & User feedback [35] \\
\hline \multirow[t]{3}{*}{ 4. Peoples } & Actors \& Roles & Role sprint [39] \\
\hline & Human resource & Team composition [25] \\
\hline & Mindset & Changing the team's mindset [25], Training the team member [42] \\
\hline 5. Environment & Regulation & $\begin{array}{l}\text { Investigate non-functional requirements regarding government } \\
\text { regulation, compliance [52] }\end{array}$ \\
\hline
\end{tabular}

\section{DISCUSSION}

This paper's main contribution is a novel approach to digital innovation, particularly in banking. Researcher identify the integration process, implications, and obstacles that banks will encounter when implementing the principles based on a literature analysis and qualitative research. In addition, as shown in Figure 9, we offer an improved framework of Design Thinking, Agile Software Development, and co-creation adoption in the context of Digital Banking Innovation.
Figure 9 shows how the concepts of co-creation, design thinking, and agile software development are integrated. All stakeholders are involved in the process of digital innovation, including (i) project manager/agile coach, (ii) product owners, (iii) developers \& engineers, (iv) compliance, (v) risk, (vi) quality assurance (QA), and (vii) advisory board.

In the first phase, the discovery, the customer is involved in the co-creation process through communities, surveys, and social media. 


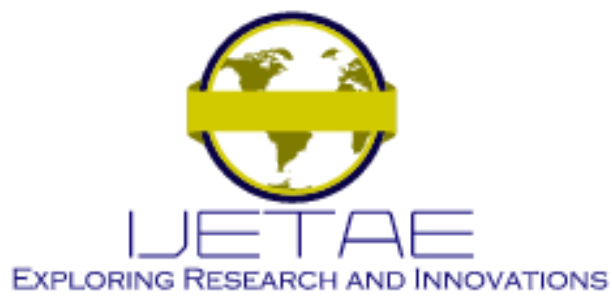

International Journal of Emerging Technology and Advanced Engineering Website: www.ijetae.com (E-ISSN 2250-2459, Scopus Indexed, ISO 9001:2008 Certified Journal, Volume 12, Issue 01, January 2022)

Other source data come from big data analytics. All data obtained from the co-creation phase will be processed into a customer's pain point, wish list, and pre-hypothesis. This information becomes the input for the discovery process.

In the second phase, the idea generation, the data from the previous discovery phase will be processed through brainstorming sessions, using the following tools: (i) product canvas, (ii) user story, (iii) empathy map, (iv) wireframe. Apart from that, compliance, risk, and security assessments are also carried out. In this phase, the team will do usability testing on the wireframe. Suppose stakeholders have approved all the requirements, it will be compiled and used as input for the development phase.

In the third stage, the development, the banks encourage adopting an agile software development process. User requirements consist of user stories, epics, non-technical requirements (risk, compliance, and security) combined with technical requirements (system environment, continuous integration, DevSecOps). The user requirements will be put in the product backlog, where all actors work together and contribute to the team as their roles require. The development of the features is based on the priorities already discussed with all the teams. The iteration process continues until the product backlog has been wholly completed. The following process, quality assurance, will perform quality control of the code and perform a user acceptance test (UAT).
The UAT is conducted to ensure that all defects and products meet the quality standard and the prototype ready for release. Once features are verified in the test phase, the finished product is ready for release.

In the fourth stage, the implementation, all the infrastructure, and environment for the live system are prepared by developers and engineers before releasing the prototype. The launching will be released incrementally and tested internally by the employee before launching to all customers to reduce the risk.

In the fifth stage, evaluation, it is necessary to measure and evaluate after the digital banking platform is released. Performance indicators of digital banking include cost, quality, usage, rating, profitability, and customer satisfaction.

\section{LIMITATION AND THREATS TO VALIDITY}

This framework was developed based on qualitative research and existing theory and literature on DT, ASD, and co-creation. The findings presented in this review study have limitations and threats to validity. Further studies provided empirical, experimental, case studies, and industrial practices adopting the framework can generalize the adoption of the concepts. Extended research can address issues regarding adopting any type and size concepts by the banking institutions. Also, there are opportunities for research on the various industries and organizations using quantitative and mixed methods for more rigorous research results. 


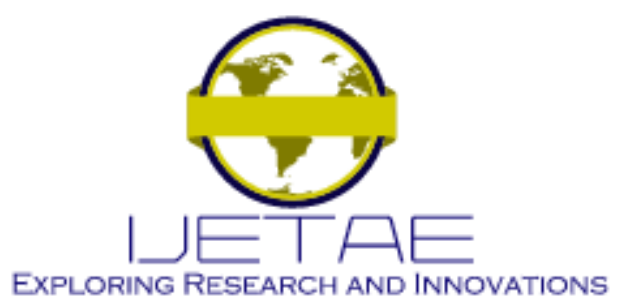

International Journal of Emerging Technology and Advanced Engineering Website: www.ijetae.com (E-ISSN 2250-2459, Scopus Indexed, ISO 9001:2008 Certified Journal, Volume 12, Issue 01, January 2022)

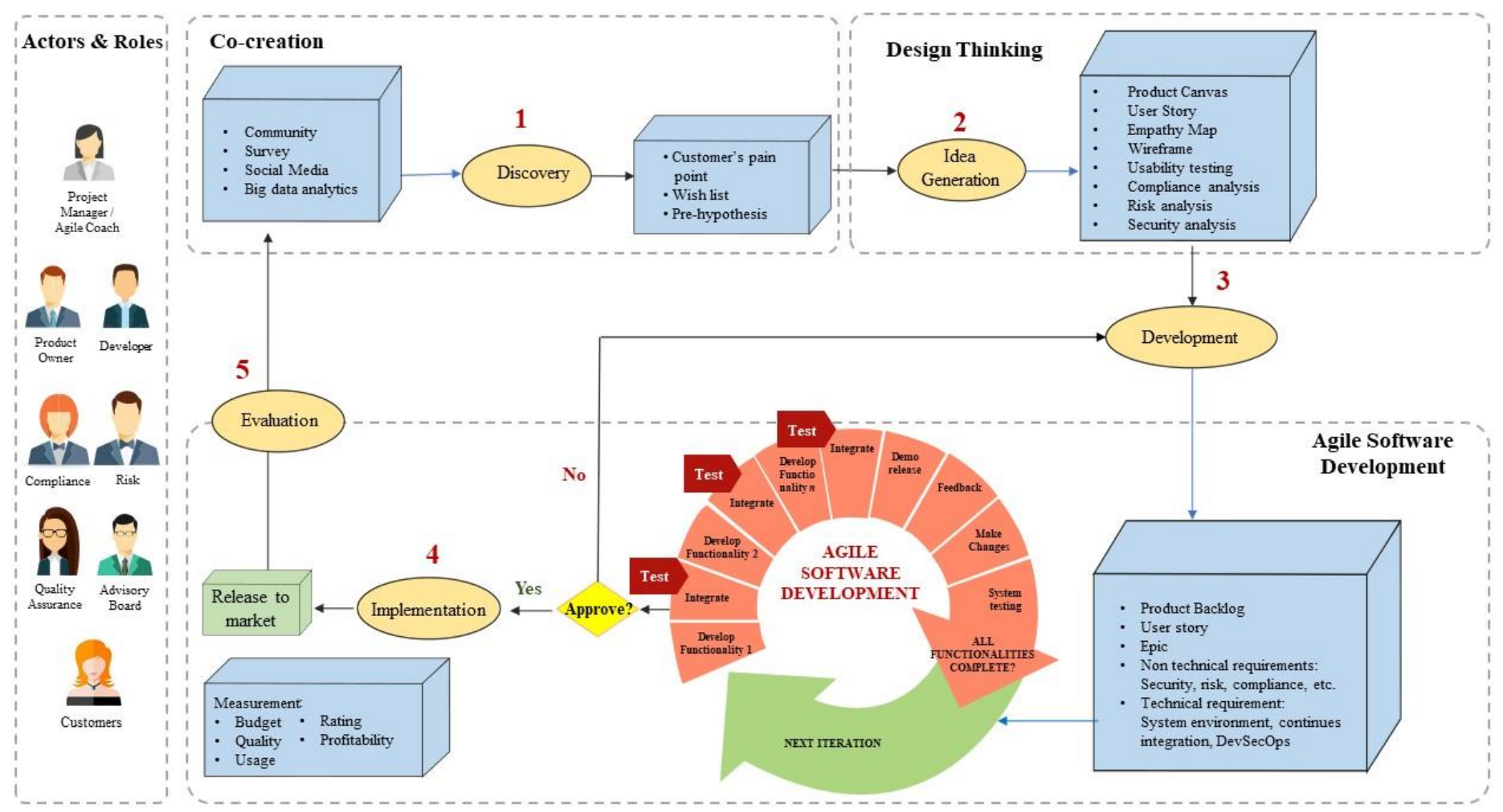

Figure 9. The integration process of Design Thinking, Agile Software Development, and Co-creation concepts

\section{CONCLUSIONS}

Increasing competition and the rapid digitalization in the financial services industry accelerated by pandemics challenges the banks to improve digital banking innovation processes. The discovery of the literature review and the result of the case study show that there are opportunities for the banking industry to adopt design thinking (DT), agile software development (ASD), and co-creation to support digital banking innovation. The interview with 3 IT Executives reveals the critical process for digital innovation to answer the research question of how to integrate DT, ASD, and co-creation in digital banking innovation. The critical process includes: (i) discovery, (ii) idea generation, (iii) development, (iv) implementation, and (v) evaluation.
We highlight the recommendations of IT Executives' for adopting the concept since they confirmed that the adoption of the main ideas significantly impacts the performance of digital banking, such as (i) high-quality digital innovation outcomes, (ii) better customer experience, (iii) faster digital product development and shorter time to market, (iv) reduce cost or budget, (v) more customer-centric digital banking platform.

The authors reveal the challenges faced by the banks when adopting DT, ASD, and co-creation, including the following factors: (i) technology, (ii) organization, (iii) process, (iv) people, (v) environment. For preventing failure in the adoption of the concepts, many strategies, approach and potential solution underline in the study. 


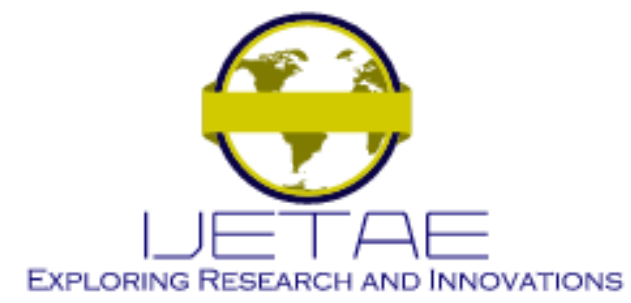

International Journal of Emerging Technology and Advanced Engineering Website: www.ijetae.com (E-ISSN 2250-2459, Scopus Indexed, ISO 9001:2008 Certified Journal, Volume 12, Issue 01, January 2022)

This paper's main contribution is a novel approach to digital innovation. The proposed integration process framework of DT, ASD, co-creation is recommended for utilizing as a guideline for adopting the concepts in the digital banking platform development. For achieving the success of digital banking innovation initiative in the future.

This framework was developed based on qualitative research and existing theory. There are limitations and validity issues for generalizing the concepts. Further research produced empirical, case studies, experimental, and industrial practices that can generalize the adoption of the concepts in any type and size of banking institutions, in other specific countries and demography.

\section{REFERENCES}

[1] J. Best, Breaking Digital Gridlock. Wiley, 2018.

[2] A. Lipton, A. Pentland, and D. Shrier, "Digital Banking Manifesto: The End of Banks?," Massachusetts Inst. Technol., pp. 1-20, 2016.

[3] C. Scardovi, Digital Transformation in Financial Services. Springer Nature, 2017.

[4] B. King, BANK 4.0: Banking Everywhere, Never at a Bank. 2018.

[5] P. Micheli, S. J. S. Wilner, S. H. Bhatti, M. Mura, and M. B. Beverland, "Doing Design Thinking: Conceptual Review, Synthesis, and Research Agenda," J. Prod. Innov. Manag., vol. 36, no. 2, pp. 124-148, 2019.

[6] S. Barquin, V. HV, and D. Shrikhande, "Digital banking in Indonesia: Building loyalty and generating growth," McKinsey Co., no. February, p. 6, 2019.

[7] T. Brown, "Deisign thinking," Harv. Bus. Rev., vol. 86, no. 6, pp. 84-92, 2008.

[8] T. Brown, Change by Design. How Design Thinking transforms Organizations and inspires Innovation. New York: Harper Collins Publishers, 2009.

[9] O. Wyman, D. Staib, S. Taylor, and I. Ania, "Design Thinking the New DNA of the financial sector," 2017.

[10] T. Dybå and T. Dingsøyr, "Empirical studies of agile software development: A systematic review," Inf. Softw. Technol., vol. 50, no. 9-10, pp. 833-859, 2008.

[11] T. Thesing, C. Feldmann, and M. Burchardt, "Agile versus Waterfall Project Management: Decision model for selecting the appropriate approach to a project," Procedia Comput. Sci., vol. 181, pp. 746756, 2021.

[12] E. D. Canedo, "The Use of Design Thinking in Agile Software Requirements Survey: A Case Study," Springer Int. Publ. AG, no. June, 2018.

[13] E. Indriasari, H. Prabowo, F. Lumban Gaol, and B. Purwandari, "The adoption of Design Thinking, Agile Software Development and Co-creation concepts A case study of Digital Banking innovation," in 2021 International Conference on Platform Technology and Service (PlatCon), 2021, pp. 7-12.

[14] K. Xie, Y. Wu, J. Xiao, and Q. Hu, "Value co-creation between firms and customers: The role of big data-based cooperative assets," Inf. Manag., vol. 53, no. 8, pp. 1034-1048, 2016.
[15] C. K. Prahalad and V. Ramaswamy, "Co-creating unique value with customers," Strateg. Leadersh., vol. 32, no. 3, pp. 4-9, 2004.

[16] M. Stickdorn and J. Schneider, This is service design thinking. 2011.

[17] D. Gomillion, "The co-creation of Information Systems," 2013.

[18] K. K. Ruusa Ligthart, Jaakko Porokuokka, "Using Digital Cocreation For Innovation Development," in International reser conference, 2016, vol. 358, pp. 1297-1306.

[19] F. Piller, A. Vossen, and C. Ihl, "From Social Media to Social Product Development : The Impact of Social Media on Co - Creation of Innovation," Die Unternehmung, vol. 66, no. 1, pp. 7-27, 2012.

[20] J. D. Creswell, John; Creswell, Research Design: Qualitative, Quantitative, and Mix Methods Approaches, Fifth Edit. SAGE Publications, 2018.

[21] Ritchie Jane; Lewis Jane, Qualitative Researh Practice: A Guide for Social Science Students and Researchers. 2003.

[22] B. Verner Kitchenham, Turner, "Systematic Literature Reviews in Global Software Development: A Tertiary Study," 16th Int. Conf. Eval. Assess. Softw. Eng. (EASE 2012), 2012.

[23] J. Matthing, "Key strategies for the successful involvement of customers in the co-creation of new technology-based services," Emerald Insight, 2007.

[24] Dhanalakshmi Arumugam Malar, "Digital Transformation in Banking: Exploring Value Co-Creation in Online Digital Transformation in Banking : Exploring Value Co-Creation in Online Banking Services in India," J. Glob. Inf. Technol. Manag., vol. 22, no. 7-24, 2019.

[25] L. Przybilla, M. Schreieck, K. Klinker, and C. Pflügler, “Combining Design Thinking and Agile Development to Master Highly Innovative IT Projects," Proj. und Vor. 2018 - Der Einfluss der Digit. auf Proj. und Entwicklungsprozesse. Gesellschaft für Inform. Bonn., pp. 113-124, 2018.

[26] et all Grashiller, Michael, "Integrated approach to the agile development with Design Thinking in an industrial environment," in International Conferene on engineering design, 2017, vol. 2, no. August, pp. 239-248.

[27] N. Alomar, N. Almobarak, and S. Alkoblan, "An Integrated Framework for Design Thinking and Agile Methods for Digital Transformation," in Design, User Experience, and Usability: Design Thinking and Methods, 2016, vol. 9746, pp. 197-208.

[28] J. Hehn and F. Uebernickel, "The use of design thinking for requirements engineering: An ongoing case study in the field of innovative software-intensive systems," Proc. - 2018 IEEE 26th Int. Requir. Eng. Conf. RE 2018, pp. 400-405, Jul. 2018.

[29] G. N. Nedeltcheva and E. Shoikova, "Coupling Design Thinking, User Experience Design and Agile," in International Conference on Big Data and Internet of Things, 2017, no. October.

[30] G. H. Steinke, M. S. Al-deen, and R. C. Labrie, "Innovating Information System Development Methodologies with Design Thinking," in The 5th International Conference on Applied Innovations in IT, (ICAIIT), 2017, no. March, pp. 51-55.

[31] M. Blaschke, "Design principles for digital value co-creation networks : a service-dominant logic perspective," Electron. Mark., pp. 443-472, 2019.

[32] D. Roberts, M. Hughes, and K. Kertbo, "Exploring consumers' motivations to engage in innovation through co-creation activities," Eur. J. Mark., vol. 48, no. 1, pp. 147-169, 2014. 


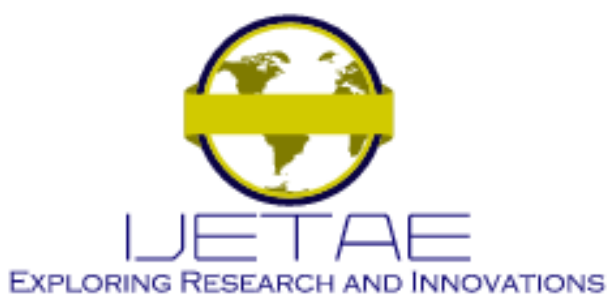

International Journal of Emerging Technology and Advanced Engineering

Website: www.ijetae.com (E-ISSN 2250-2459, Scopus Indexed, ISO 9001:2008 Certified Journal, Volume 12, Issue 01, January 2022)

[33] W. D. Hoyer, R. Chandy, M. Dorotic, M. Krafft, and S. S. Singh, "Consumer Cocreation in New Product Development," J. Serv. Res., 2010.

[34] P. Frow, A. Payne, P. Frow, S. Nenonen, A. Payne, and K. Storbacka, "Managing Co-creation Design : A Strategic Approach to Innovation,” Br. J. Manag., no. February 2015, 2015.

[35] L. Corral and I. Fronza, "Design Thinking and Agile Practices for Software Engineering: An Opportunity for Innovation Design Thinking and Agile Practices for Software Engineering," in SIGITE, 2018, no. November.

[36] S. Adikari, C. Mcdonald, and J. Campbell, "Reframed Contexts : Design Thinking for Agile User Experience Design Reframed Contexts: Design Thinking," Springer - Verlag Berlin Heidelb. 2013, no. July, 2013.

[37] J. Kim and H. Choi, "Value co-creation through social media: A case study of a start-up company," J. Bus. Econ. Manag., vol. 20, no. 1, pp. 1-19, 2019.

[38] M. Schreieck and M. Wiesche, "How established companies leverage co-creation insight from banking," AIS Electron. Libr., vol. 2017, pp. 1726-1741, 2017.

[39] E. Dias et al., "Design Thinking Use in Agile Software Projects : Software Developers 'Perception," in 22nd International Conference on Enterprise Information Systems, 2019.

[40] F. Kohlbacher, "Knowledge-based New Product Development: fostering innovation through knowledge co-creation," Int. J. Technol. Intell. Plan., vol. 4, no. 3, pp. 326-346, 2008.

[41] H. F. Martins, A. C. de Oliveira, E. D. Canedo, R. A. D. Kosloski, R. Á. Paldês, and E. C. Oliveira, "Design thinking: Challenges for software requirements elicitation," Inf., vol. 10, no. 12, pp. 1-27, 2019.

[42] T. Franziska Hager, Kowark, J. Kru, C. Vetterli, and M. Uflacker, "DT@ Scrum: Integrating Design Thinking with Software Development Processes," Springer, pp. 263-289, 2015.
[43] S. Ben Mahmoud-jouini and C. Midler, "Contributions of Design Thinking to Project Management in an Innovation Context," Wiley Online Libr., no. October 2018, 2016.

[44] F. Piller, A. Vossen, and C. Ihl, "From Social Media to Social Product Development : The Impact of Social Media on Co - Creation of Innovation," pp. 1-22, 2012.

[45] J. Cesar and R. D. F. S. M. Russo, "Design Thinking Integrated in Agile Software Development: A Systematic Literature Review," Procedia Comput. Sci., vol. 138, pp. 775-782, 2018.

[46] C. M. Hasso Plattner, "Design Thinking Research: Studying cocreation in practice," Springer Proc. Bus. Econ., 2012.

[47] M. Bartl, G. Jawecki, and P. Wiegandt, "Co-Creation in New Product Development: Conceptual Framework and Application in the Automotive Industry," no. March, 2014.

[48] B. Aquilani, C. Silvestri, and A. Ruggieri, "Sustainability, TQM and Value Co-Creation Processes: The Role of Critical Success Factors," MDPI, 2016.

[49] K. Dikert, M. Paasivaara, and C. Lassenius, "Challenges and success factors for large-scale agile transformations: A systematic literature review,” J. Syst. Softw., vol. 119, pp. 87-108, 2016.

[50] J. Cesar and R. D. F. S. M. Russo, “A Design Thinking Systematic Integrated in Agile Software Literature Review Development: A Systematic Literature Review," Procedia Comput. Sci., vol. 138, pp. 775-782, 2018.

[51] T. Stober and U. Hansmann, Agile software development: Best practices for large software development projects. 2010.

[52] J. Hehn, "The Use of Design Thinking for Requirements Engineering," in 26th IEEE International Requirements Engineering Conference, 2018. 